\title{
University Course Scheduling and Classroom Assignment ${ }^{1}$
}

\section{Programación de horarios y asignación de aulas de clases universitarias $^{2}$}

\author{
Camilo Torres-Ovalle ${ }^{3}$ \\ Jairo R. Montoya-Torres ${ }^{4}$ \\ Carlos L. Quintero-Araújo \\ Angélica Sarmiento-Lepesqueur ${ }^{6}$ \\ Mónica Castilla-Luna
}

DOI:10.11144/JaVERIANA.IYU18-1.PHAA

\begin{abstract}
' Received: May $16^{\text {th }}, 2013$. Accepted: February 13 $3^{\text {th }}$, 2014. Work carried out by research group Logística y Negocios Internacionales from Universidad de La Sabana, Chía, Colombia, within the framework of research project CEA-24-2008. The work of the fourth author was also supported under a postgraduate scholarship from the Master Program in Operations Management, Universidad de La Sabana. Authors wish to acknowledge the administrative and academic board (e.g., Dirección de Registro Académico, Dirección de Currículo), from Universidad de La Sabana, for their support, availability and insights during the development of this research.

${ }^{2}$ Fecha de recepción: 16 de mayo de 2013. Fecha de aceptación: 13 de febrero de 2014. Desarrollado por el grupo de investigación Logística y Negocios Internacionales de la Universidad de La Sabana, Chía, Colombia. Los autores expresan sus agradecimientos a las directivas académicas y administrativas (e. g. Dirección de Registro Académico, Dirección de Currículo) de la Universidad de La Sabana, por el apoyo, la disposición y los aportes durante el proceso de investigación. ${ }^{3}$ Finance and Systems Administrator, Fundación Universitaria Agraria de Colombia, Bogotá, Colombia. Master in Operations Management, Universidad de La Sabana, Chía, Colombia. Head of Curricula Management, Universidad de La Sabana. E-mail: camilo.torres@unisabana.edu.co.

${ }^{4}$ Industrial engineer, Universidad del Norte, Barranquilla, Colombia. PhD in Industrial Engineering, Ecole Nationale Supérieure des Mines de Saint-Etienne and Université Jean Monnet, Saint-Etienne, France. Postdoctoral diploma on Research Direction (HDR), INSA de Lyon and Universidad Claude Bernard, Lyon, France. Full professor, Universidad de La Sabana, Chía, Colombia. E-mail: jairo.montoya@unisabana.edu.co.

${ }^{5}$ Industrial engineer, Pontificia Universidad Javeriana, Bogotá, Colombia. Master in Optimization and Systems Security, Université de Technologie de Troyes, France. Director of International Marketing and Logistics Management Program, Universidad de La Sabana, Chía, Colombia. E-mail: carlos.quintero5@unisabana.edu.co.

${ }^{6}$ Industrial Engineer, Escuela Colombiana de Ingeniería Julio Garavito, Bogotá, Colombia. Master in Operations Management, Universidad de La Sabana, Chía, Colombia. Lecturer, Escuela Colombiana de Ingeniería Julio Garavito, Bogotá, Colombia. E-mail: angelica.sarmiento@escuelaing.edu.co.

${ }^{7}$ Doctor in medicine, Universidad del Rosario, Bogotá, Colombia. Master of Sciences, Instituto Nacional de Salud Pública, Colombia. Director of Curricula, Universidad de La Sabana, Chía, Colombia. E-mail: monica.castilla@unisabana.edu.co.
\end{abstract}




\section{$\Delta \nabla$}

This paper studies a real-life course timetabling and classroom assignment problem found at Universidad de La Sabana, Colombia. The problem is characterized and modeled using integer linear programming. Because of its complexity in the number of decision variables and constraints, a hierarchical two-phase solution approach is proposed: course timetabling firstly, and classroom assignment, secondly. The approach is validated using real data from the first semester of year 2012. Results show that the proposed approach obtains a better utilization of classrooms satisfying both hard and soft constraints of the original problem. A sensitivity analysis is finally carried out, in which it was possible to verify the possibility of reducing both the number of classrooms to be assigned and the number of course groups. Both analyses allow an increase in teaching resource availability and a reduction of total cost.

\section{地粗口}

Course timetabling, classroom assignment, integer linear programming.

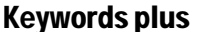

Class periods, classrooms - programming.

\section{婌以门料}

Este artículo considera el problema real de programación de horarios de clases universitarias y asignación de salones en la Universidad de La Sabana, Colombia. El problema es caracterizado y modelado empleando programación lineal entera. Debido a su alta complejidad en el número de variables de decisión y de restricciones, se propone un enfoque de solución secuencial de dos fases: primero, asignación de horarios a las materias, y segundo, asignación de salones. Este método de resolución es validado empleando datos reales del primer semestre académico de 2012. Los resultados muestran que el enfoque propuesto permite obtener una mejor utilización de los salones, al mismo tiempo que se satisfacen las restricciones duras y blandas del problema original. Se realiza también un análisis de sensibilidad con el cual fue posible verificar la posibilidad de reducir tanto el número de salones que se van a asignar como el número de grupos de cada materia. Ambos análisis incrementan la disponibilidad de los recursos docentes y reducen los costos de la programación.

\section{5 $107 \%$ *}

Programación de clases, asignación de salones, programación entera.

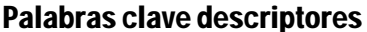

Periodos lectivos - programación, salones de clase - programación. 


\section{Introduction}

Each academic period, universities must face the problem of course timetabling and classroom assignment for each course offered by the different graduate and undergraduate programs. From the Operations Research literature point of view, this problem is a particular case of the general timetabling problem (Hernández et al. 2008). Since, in general, these academic institutions have limited physical infrastructure and educational resources, the problem consists of the assignment of both classrooms and resources (lecturers, audio visual media, etc.) to a set of courses that students must follow according to their curricula. In the academic literature, several authors such as Schaerf (1999), Burke and Petrovic (2002) and Pillay (2013) have proposed other formal definitions of this problem. The final solution must satisfy both hard and soft constraints. In general terms, it is required that courses or associated events must be scheduled in predefined time slots in order to firstly allow the students to have some flexibility when choosing their courses; secondly to allow lecturers and teachers to carry out other administrative and research activities, and finally, to guarantee a good level of infrastructure utilization. For that reason, academic institutions invest considerable amount of time for planning and scheduling these resources.

Although the great advances on the design of sophisticated optimization algorithms, there is still a huge concern regarding their actual utility in real practice (McCollum, 2007). Indeed, the development of computers has allowed the researchers to design efficient meta-heuristics procedures to solve hard combinatorial optimization problems. However, most of these algorithms usually focus on the resolution of academic problems found in the literature that do not necessary capture the actual complexity of real-life decision making. Timetabling is one of these research areas (McCollum, 2007). As a consequence, although the advances in the academic literature regarding the resolution of class timetabling problems using randomized datasets (benchmarks) (Socha $e t$ al., 2002; Rossi-Doria et al., 2003; Abdullah et al., 2005), there is no evidence that these works take into account realistic constraints or that they have been 
actually implemented at the universities (McCollum, 2007). As a matter of fact, the work of Carter and Laporte (1998) clearly state that these authors were 'somewhat surprised to discover that there are very few course timetabling papers that actually report that the (research) methods have been implemented and used in an institution'. These conclusions were reported in 1998 but the study of McCollum (2007) published 10 years later reported the same conclusions.

One of the strategies to reduce this gap between theoretical developments and actual implementation in institutions of models and algorithms consists on highlighting the relevance of particular issues of each university (McCullan, 2007). From this premise, the objective of this paper is to propose a mathematical model representing the characteristics of the course timetable and classroom assignment problem at Universidad de La Sabana, Colombia. In addition, because of the complexity of this optimization problem, this paper also proposes an efficient solution method that seeks to improve current performance metrics regarding the utilization level of the physical infrastructure at the university.

\section{Overview of Related Literature}

The academic literature has witnessed the publication of large amount of works studying the course timetabling problem. State of the art surveys are proposed by Schaerf (1999), Burke and Petrovic (2002) and Pillay (2013). This subsection does not intend to be exhaustive on presenting another review of scientific literature; the interested reader may refer to those previous works. The objective of this subsection is hence to give an overview of how the course timetable and classroom assignment problem has been approached in the academic literature (e.g., family of resolution methods).

Usually, the problem under study in this paper is presented as a variant of the exam scheduling problem (Shaerf, 1999). However, there are some differences that make the course timetable and classroom assignment problem much more complex. In particular, as stated previously, there exist some hard constraints related with the curricula (set of courses per academic period) that student must follow to complete their academic program. In general terms, solution approaches can be classified into sequential methods, clustering methods, constraint satisfaction procedures, and meta-heuristics. When applying sequential methods, the problem is usually modeled as a graph in which the nodes represent the events (courses) and the arcs represent the conflicts between events (de Werra, 1985). In clustering methods, the set of events is partitioned in groups satisfying the hard constraints and then these groups are assigned to time slots 
in order to satisfy the soft constraints. In constraint satisfaction approaches, the problem is modeled with a set of variables (e.g. events) that must be assigned to a set of resources. Most of models based on binary linear programming fall into this category. Finally, meta-heuristic methods are computational techniques that capture the problem complexity and solve it efficiently. The literature review presented by Lewis (2008) is only focused on the application of meta-heuristic procedures to solve the timetabling problem.

On the other hand, to the extent that it has been observed that universities have permanently been growing on number of students, the need of automated timetable systems has increased (Burke and Petrovic, 2002). In practice, the construction of a solution is very often limited to found any solution satisfying the constraints (Schaerf, 1999). From the software point of view, any of these solutions is considered a good solution and the concept of "optimum timetable" is not of interest for schedulers' daily tasks (McCollum, 2007). Some works in the literature have been interested in solving this situation (e.g., Carter and Laporte, 1998; Carter, 2001; Rossi-Doria et al., 2003; Abdullah et al., 2005; Konstantinow and Coakley, 2005). Despite those advances, the resolution of this problem still requires the intervention of humans, to the point that sometimes the problem is completely solved manually.

\section{Problem Statement}

Currently, the classroom assignment process at Universidad de La Sabana is carried out by the Administrative Director. Classrooms are assigned using the information available within the academic database and entered by Academic and Administrative Coordinators of each academic unit after the student registration period. Afterwards, these assignments are verified manually. These tasks may take between two to three days per academic unit, hence requiring a total of about three weeks for the whole university. In addition, the process depends completely on the expertise of the employee in charge. The aim of this paper is to propose a formal methodology based on mathematical optimization to solve the course timetable and classroom assignment problem at Universidad de La Sabana.

In order to define the scope of this research, it has been decided to run a pilot experiment representative enough of the actual process complexity. The information employed was supplied by the Direction of Academic Affairs (Jefatura de Registro Académico), corresponding to the number of undergraduate students registered in the first semester of the academic year 2012. Figure 1 presents 
the Pareto distribution of undergraduate students of the 20 academic programs per academic unit and per program. It is observed that the School of Economics and Administrative Sciences (EICEA for its name in Spanish) and the Faculty of Engineering represent both the $44.64 \%$ of the total student population. In addition, it is important to highlight that these two units offer ten undergraduate programs (e.g., $50 \%$ of the number of undergraduate programs in the university). Another important point is that such undergraduate programs require a considerable diversity of teaching resources, including specialized labs, classrooms, etc. Some programs have a relevant number of students allowing the creation of several groups for a given subject, while other programs have few students allowing the analysis of timeslot conflicts between courses of the same academic semester. Finally, the Faculty of Engineering and the EICEA offer the $48.71 \%$ of the total number of courses offered at the university.

Figure 1. Pareto charts: (a) Per Students and (b) Per Module

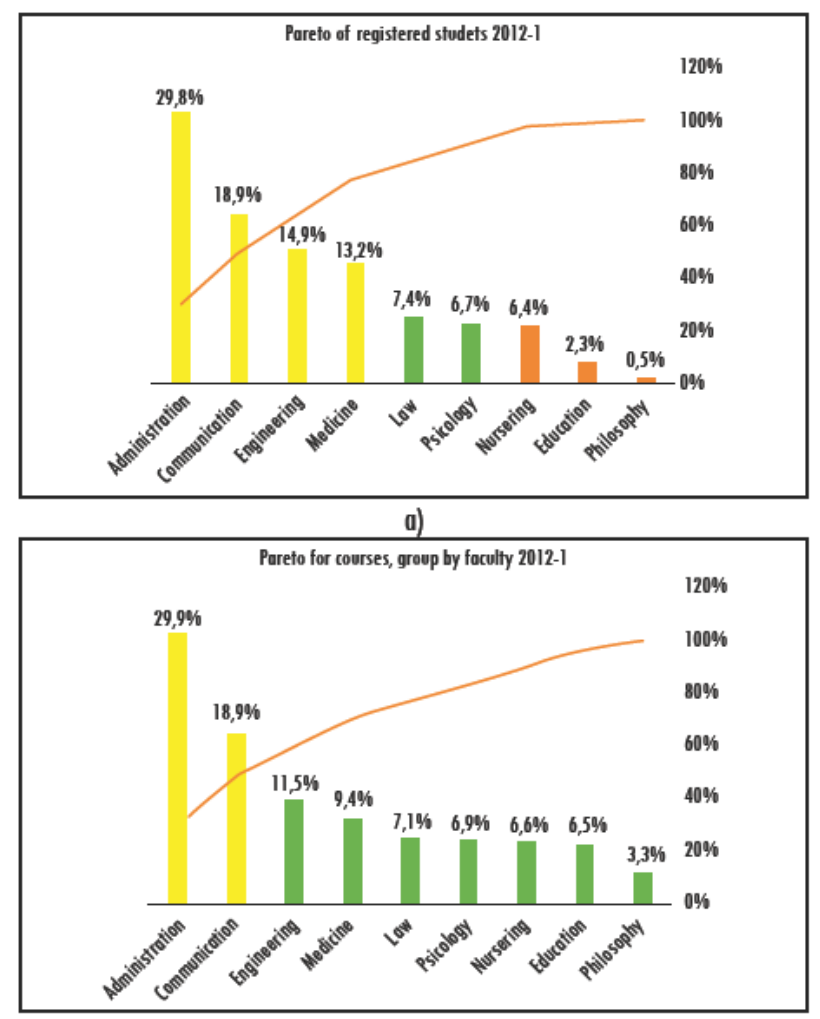

b)

Source: Universidad de La Sabana (2012). 
As a conclusion, the analysis of these two academic units is a representative sample of the whole complexity of the process at the university and allows the validation of the methodology proposed in this paper. It will be possible to extrapolate the conclusions for further implementation at different levels within the university as well as within other universities. Following sections present in detail the proposed approach, including the mathematical model and the resolution approach, as well as the numerical results of the implementation.

\section{Methods}

A first approximation to this problem was presented in the work of SarmientoLepesqueur et al. (2011), considering only the undergraduate program of International Marketing and Logistics Administration, employing a binary programming model. The current paper seeks at solving the global problem for the whole university. The goal is to take into account a greater number of undergraduate programs. The components of the proposed mathematical model are presented next:

Sets

$\mathrm{I}=$ timeslots $\{\mathrm{F} 1, \mathrm{~F} 2, \ldots, \mathrm{F} 64\}$

$\mathrm{J}=$ courses (each element referes to a group of each subject $\{\mathrm{M} 1, \mathrm{M} 2, \mathrm{M} 3 \ldots\}$

$\mathrm{L}=$ available classrooms $\{\mathrm{L} 1, \mathrm{~L} 2, \ldots, \mathrm{L} 53\}$

$\mathrm{K}=$ available lecturers $\{\mathrm{P} 1, \mathrm{P} 2, \ldots, \mathrm{P} 276\}$

$\mathrm{M}=$ semester to which one subject may belong $\{\mathrm{S} 1, \mathrm{~S} 2, \ldots, \mathrm{S} 10\}$

$\mathrm{N}=$ working days $\{\mathrm{D} 1, \mathrm{D} 2, . ., \mathrm{D} 6\}$

\section{Parameters}

$\mathrm{INTH}_{(\mathrm{J})}=$ number of time slots that must have each course or subject $\mathrm{J}$

$\mathrm{TG}_{(\mathrm{J})}=$ number of expected students for each course $\mathrm{J}$

$\mathrm{TS}_{(\mathrm{L})} \quad=$ installed capacity (in number of students) of classroom $\mathrm{L}$

$\mathrm{MS}_{(\mathrm{J}, \mathrm{M})}=$ matrix with cell value 1 if subject $\mathrm{J}$ belongs to semester $\mathrm{M}, 0$ otherwise

$\mathrm{MP}_{(\mathrm{J}, \mathrm{K})}=$ matrix with cell value 1 if lecturer $\mathrm{K}$ teaches subject $\mathrm{J}$, = otherwise

$\mathrm{FD}_{(\mathrm{I}, \mathrm{N})}=$ matrix with cell value 1 if timeslot $\mathrm{I}$ is on day $\mathrm{N}, 0$ otherwise

$\mathrm{FM}_{(\mathrm{J}, \mathrm{I})}=$ matrix with cell value 1 if timeslot I may be assigned to subject $\mathrm{J}, 0$ otherwise

$\mathrm{FP}_{(\mathrm{I}, \mathrm{K})}=$ matrix with cell velue 1 if lecturer $\mathrm{K}$ can teach at timeslot $\mathrm{I}, 0$ otherwise 
$\mathrm{CFM}_{(\mathrm{J}, \mathrm{I})}=$ matrix containing the weights of each timeslot (values between 2 and 9)

$\mathrm{MA}_{(\mathrm{J}, \mathrm{L})}=1$ if subject $\mathrm{J}$ can be assigned to classroom $\mathrm{L}, 0$ otherwise

Decision variables

$\mathrm{X}_{\mathrm{I}, \mathrm{J}, \mathrm{L}}=\{1$ if timeslot $\mathrm{I}$ is assigned to subject $\mathrm{J}$ on classroom $\mathrm{L} 0$ otherwise $\}$

Objective function:

$$
\min Z=\sum_{I \in C F M} \sum_{J \in F M} \sum_{L} C F M_{I, J} * X_{I J L}
$$

Constraints:

$\sum_{J} X_{I J L} \leq 1 ; \forall_{1}, \forall_{L}$

$\sum_{L_{\in M A}} X_{I J L} \leq 1 ; \forall_{I \in F M}, \forall_{J}$

$\sum_{L_{\epsilon F M}} \sum_{L \in F M \in M A} X_{I J L}=I N T H_{J} ; \forall_{J}$

$X_{I J L} * T G_{J} \leq T S_{L} ; \forall_{I \in N F}, \forall_{J \in M F} \forall_{L}$

$\sum_{J_{\in M F}} \sum_{L \in M A} X_{I J L} \leq 1 ; \forall_{K}, \forall_{I \in M F}$

$\sum_{J_{\in M S}} \sum_{L_{\in M A}} X_{I J L} \leq 1 ; \forall_{M}, \forall_{1}$

$\sum_{J_{\in F D}} \sum_{L_{\in M A}} X_{I J L} \leq 3 ; \forall_{N}, \forall_{J \in P B}$

$X_{I, J, L} \in\{0,1\} ; \forall_{I}, \forall_{J}, \forall_{L}$ 
Objective function (1) seeks at minimizing the sum of all possible assignments multiplied by the cost matrix of each timeslot. This matrix represents the weighting of each timeslot according to the availability of lecturers. This weighting is expressed in "monetary units" (u.m.). Since this is a minimization problem, "most desirable" timeslots have the lowest weights (see Table 1). These are arbitrary values and were defined for the particular case under study in this paper based on institutional requirements (preference to keep free the timeslot of midday for lunch).

Table 1. Weights (in u.m.) of Timeslots

Required in the Objective Function

\begin{tabular}{|c|c|}
\hline Hour & Weight \\
\hline 07:00 a.m. & 2 \\
\hline 08:00 a.m. & 2 \\
\hline 09:00 a.m. & 3 \\
\hline 10:00 a.m. & 3 \\
\hline 11:00 a.m. & 4 \\
\hline 12:00 p.m. & 7 \\
\hline 01:00 p.m. & 7 \\
\hline 02:00 p.m. & 5 \\
\hline 03:00 p.m. & 2 \\
\hline 04:00 p.m. & 2 \\
\hline 05:00 p.m. & 3 \\
\hline 06:00 p.m. & 5 \\
\hline
\end{tabular}

Source: Torres Ovalle (2013).

Constraints (2) and (3) ensure that each classroom assigned only once to a timeslot, so that any classroom at a given timeslot has only one course assigned. Constraints (4) ensure that the total number of hours required to teach all subjects are scheduled. Constraints (5) guarantee that classrooms with enough capacity are selected for each course according to the number of expected students. Constraints (6) ensure that courses taught by a given lecturer are not scheduled at the same timeslot. In addition, it is important that subjects of a given program in a given semester are not scheduled at the same time. This is ensured by Constraints (7). On the other hand, if a given course is scheduled to be taught in a block of several hours, for pedagogical reasons the block must not exceed three hours. Constraints (8) guarantee this condition. Finally, Constraints (9) correspond to binary values of decision variables. 
Because of the size of the dataset (2,157,120 discrete variables and 873,096 constraints), it is not practical to develop a decision aid tool based on this model to solve the problem when applied to all undergraduate and postgraduate academic programs offered by the university. Hence, a heuristic solution is next proposed in which the problem is solved sequentially.

In the first phase of the heuristic procedure, the general matrix is organized by academic programs, then by semester and finally by course or subject. The methodology employed started the timetabling of academic programs with small number of groups. Once the mathematical model became very complex, computationally speaking, the problem is solved by academic semester. Table 2 summarizes the list of undergraduate programs and how they were solved: complete solution or solution by semester. Seven programs are solve completely using the model, with up to 75 groups.

Table 2. Iterative Heuristic Solution

\begin{tabular}{|r|l|c|c|c|c|}
\hline ID & \multicolumn{1}{|c|}{ Academic Program } & $\begin{array}{c}\text { Number } \\
\text { of } \\
\text { Subjects }\end{array}$ & $\begin{array}{c}\text { Number } \\
\text { of } \\
\text { Groups }\end{array}$ & $\begin{array}{c}\text { Complete } \\
\text { Solution }\end{array}$ & $\begin{array}{c}\text { Solution } \\
\text { by } \\
\text { Semester }\end{array}$ \\
\hline 1 & Chemical Engineering & 29 & 35 & $\mathrm{X}$ & \\
\hline 2 & $\begin{array}{l}\text { International Marketing and Logistics } \\
\text { Administration }\end{array}$ & 41 & 44 & $\mathrm{X}$ & \\
\hline 3 & Informatics Engineering & 34 & 45 & $\mathrm{X}$ & \\
\hline 4 & Economics and International Finance & 36 & 48 & $\mathrm{X}$ & \\
\hline 5 & Service Institutions Administration & 52 & 52 & $\mathrm{X}$ & \\
\hline 6 & Gastronomy & 45 & 68 & $\mathrm{X}$ & \\
\hline 7 & Industrial Engineering & 40 & 75 & $\mathrm{X}$ & \\
\hline 8 & International Business Administration & 46 & 105 & & $\mathrm{X}$ \\
\hline 9 & Business Administration & 53 & 108 & & $\mathrm{X}$ \\
\hline 10 & Agroindustrial Production Engineering & 39 & 117 & & $\mathrm{X}$ \\
\hline & TOTAL & 415 & 697 & & \\
\hline
\end{tabular}

Source: Universidad de La Sabana 2012 and experimental results.

At the end of the second phase, the courses scheduled in blocks do not change the assigned classroom. To do so, constraints in the mathematical model containing sums over the set $\mathrm{L}$ of classrooms are modified by including the parameter $\mathrm{MA}_{(\mathrm{J}, \mathrm{L})}$ as input. 


\section{Results}

The mathematical model was solved using GAMS (General Algebraic Modeling System) version 21.1. Numerical experiments were run on a PC with processor Intel Core i5 and $8 \mathrm{~GB}$ of RAM. The model solved the classroom assignment in reasonable computational times without violating the constraints. Soft constraints, such as classroom preference of lecturers and unauthorized classroom change when scheduled in bocks, are also respected. Because of length restrictions for this paper, only consolidated results for all the ten academic programs are presented next. Afterwards, a sensibility analysis is developed in order to have some insights about the robustness of the proposed model. The final goal is to provide some inputs allowing the improvement of the academic information systems at the university.

\subsection{Consolidated Results}

A consolidated analysis of results obtained with the mathematical model is presented next, as well as a comparison with the current timetabling applied at the university. Table 3 presents the comparison between courses scheduled in blocks, showing the behavior and variation between timetables. The model scheduled four blocks of four hours (due to availability of assigned lecturers), in which case the constraint of no more than three hours per block was relaxed. The last row of the table shows the values of the objective function. The current solution provided by the university, the final objective value is $7,421 \mathrm{u} . \mathrm{m}$. while the model obtains a final value of 4,782 u.m. (this is $35.6 \%$ lower).

Table 3. Comparison between Actual and Proposed Timetabling

\begin{tabular}{|l|c|c|c|c|c|}
\hline \multirow{2}{*}{} & \multicolumn{2}{|c|}{ Current schedule } & \multicolumn{2}{c|}{ Proposed model } & \\
\cline { 2 - 7 } & All subjects & $\begin{array}{c}\text { \% All } \\
\text { subjects }\end{array}$ & All subjects & $\begin{array}{c}\% \text { All } \\
\text { subjects }\end{array}$ & Dif. (\%) \\
\hline No blocks & 49 & 7.0 & 149 & 21.4 & 204.1 \\
\hline Blocks 2 hours & 554 & 79.5 & 433 & 62.1 & -21.8 \\
\hline Blocks 3 hours & 76 & 10.9 & 111 & 15.9 & 46.1 \\
\hline Blocks 4 hours & 17 & 2.4 & 4 & 0.6 & -76.5 \\
\hline Blocks 5 hours & 1 & 0.1 & 0 & 0.0 & -100.0 \\
\hline Solution value & \multicolumn{7}{|c|}{7421} & 4782 & -35.6 \\
\hline
\end{tabular}

Source: Torres Ovalle (2013). 
Table 4 presents the consolidated comparison of utilization level of each timeslot. It is observed that the timeslots with higher utilization ratio are 8:00 a.m. - 9:00 a.m. (91.3\%), 4:00 p.m. - 5:00 p.m. (91\%) and 7:00 a.m. - 8:00 a.m. $(87.4 \%)$, while in the current timetable, the timeslot with higher utilization levels is 10:00 a.m. - 11:00 a.m. (62.5\%). It must be noticed that the proposed solution allows a considerable reduction on the utilization level of classrooms at midday (only 9.8\% of classrooms are used between 12:00 p.m. and 2:00 p.m.). This is consistent with the particular soft constraint of the university.

Table 4. Consolidated Comparison of Utilization Level of Timeslots

\begin{tabular}{|l|c|c|}
\hline Time slot & $\begin{array}{c}\text { Current } \\
\text { Schedule (\%) }\end{array}$ & $\begin{array}{c}\text { Proposed } \\
\text { model (\%) }\end{array}$ \\
\hline 07:00 a.m. & 61.2 & 87.4 \\
\hline 08:00 a.m. & 60.4 & 91.3 \\
\hline 09:00 a.m. & 45.0 & 75.6 \\
\hline 10:00 a.m. & 62.5 & 68.6 \\
\hline 11:00 a.m. & 47.2 & 43.6 \\
\hline 12:00 p.m. & 43.2 & 11.6 \\
\hline 01:00 p.m. & 43.6 & 8.1 \\
\hline 02:00 p.m. & 45.7 & 17.3 \\
\hline 03:00 p.m. & 39.2 & 82.0 \\
\hline 04:00 p.m. & 37.8 & 91.0 \\
\hline 05:00 p.m. & 30.3 & 68.3 \\
\hline 06:00 p.m. & 16.1 & 30.8 \\
\hline
\end{tabular}

Source: Torres Ovalle (2013).

\subsection{Sensitivity Analysis}

The analysis presented in this subsection has two main objectives. On the first hand, the goal is to identify which assigned classrooms have a relatively low utilization level (about 50\%), meaning that it could be possible to better use the installed capacity. On the other hand, the initial data processing allowed identifying that some programs have several groups with 10 to 20 students registered. Assuming that there are no special pedagogical conditions, it is desirable to know if it is possible to consolidate groups in order to reduce the level of resource requirements. 


\subsubsection{Reducing the Number of Classrooms}

Table 5 presents a comparison between utilization levels of classrooms for both initial and final solutions obtained with the model. The initial solution had a total of 60 classrooms. After the sensitivity analysis, this set was reduced to 46 classrooms (30.4\% of reduction). As a consequence, the occupancy level was increased to $74.06 \%$. Regarding the utilization of each timeslots, both the initial and final solutions present similar values, as shown in Table 6 . Indeed, the average use of timeslots in the real timetable is $44.3 \%$, in the initial mathematical solution is $56 \%$ and the final timetable is $70 \%$. The value of the objective function increases to a total of 6,407 u.m. with respect to the initial solution. However, this value is still better than the current university timetable: an improvement of 1,014 u.m. is obtained, which represents a decrease of $15.8 \%$.

Table 5. Results After Reducing the Number of Classrooms

\begin{tabular}{|c|c|c|c|c|c|c|}
\hline \multirow[b]{2}{*}{ Program } & \multicolumn{3}{|c|}{ Initial Solution } & \multicolumn{3}{|c|}{ Classroom Reduction Solution } \\
\hline & $\begin{array}{c}\mathrm{H} / \\
\text { Sem. }\end{array}$ & Classrooms & $\begin{array}{c}\% \\
\text { Occupancy }\end{array}$ & $\begin{array}{c}\mathrm{H} / \\
\text { Sem. }\end{array}$ & Classrooms & $\begin{array}{c}\% \\
\text { Occupancy }\end{array}$ \\
\hline Chemical Engineering & 86 & 3 & 44.79 & 86 & 2 & 67.19 \\
\hline $\begin{array}{l}\text { International } \\
\text { Marketing and Logistics } \\
\text { Administration }\end{array}$ & 118 & 4 & 46.09 & 118 & 3 & 64.84 \\
\hline Informatics Engineering & 111 & 4 & 43.36 & 111 & 2 & 86.72 \\
\hline $\begin{array}{l}\text { Economics and } \\
\text { International Finance }\end{array}$ & 162 & 4 & 63.28 & 162 & 3 & 84.38 \\
\hline $\begin{array}{l}\text { Service Institutions } \\
\text { Administration }\end{array}$ & 158 & 4 & 61.72 & 158 & 3 & 82.29 \\
\hline Gastronomy & 216 & 6 & 56.25 & 216 & 4 & 84.38 \\
\hline Industrial Engineering & 180 & 5 & 56.25 & 180 & 4 & 70.31 \\
\hline $\begin{array}{l}\text { International Business } \\
\text { Administration }\end{array}$ & 358 & 12 & 46.61 & 358 & 10 & 55.94 \\
\hline Business Administration & 315 & 8 & 61.52 & 315 & 6 & 82.03 \\
\hline \multirow[t]{2}{*}{$\begin{array}{l}\text { Agroindustrial } \\
\text { Production Engineering }\end{array}$} & 360 & 10 & 56.25 & 360 & 9 & 62.50 \\
\hline & & 60 & 53.61 & & 46 & 74.06 \\
\hline
\end{tabular}

Source: Torres Ovalle (2013). 
Table 6. Comparison of Classroom Utilization Levels Reducing the Number of Classrooms

\begin{tabular}{|l|l|l|l|}
\hline Time slot & Current Schedule (\%) & Proposed model (\%) & $\begin{array}{c}\text { Classrooms reduction } \\
\text { solution (\%) }\end{array}$ \\
\hline 07:00 a.m. & 61.2 & 87.4 & 93.0 \\
\hline 08:00 a.m. & 60.4 & 91.3 & 93.8 \\
\hline 09:00 a.m. & 45.0 & 75.6 & 88.2 \\
\hline 10:00 a.m. & 62.5 & 68.6 & 84.5 \\
\hline 11:00 a.m. & 47.2 & 43.6 & 70.5 \\
\hline 12:00 p.m. & 43.2 & 11.6 & 19.9 \\
\hline 01:00 p.m. & 43.6 & 8.1 & 19.9 \\
\hline 02:00 p.m. & 45.7 & 17.3 & 47.1 \\
\hline 03:00 p.m. & 39.2 & 82.0 & 96.7 \\
\hline 04:00 p.m. & 37.8 & 91.0 & 95.7 \\
\hline 05:00 p.m. & 30.3 & 68.3 & 84.5 \\
\hline 06:00 p.m. & 16.1 & 30.8 & 45.7 \\
\hline
\end{tabular}

Source: Torres Ovalle (2013).

\subsubsection{Group Consolidation}

The original timetabling problem is composed of a total of 2066 hours of lectureship per week to be scheduled. During the data processing stage, it was observed that some programs have the same subject with different registration code and with about 20 students. The goal is hence to analyze the performance of the mathematical model by integrating possible groups belonging to a given academic program. This process allows a reduction of $19.5 \%$ in the number of lectureship hours to be scheduled (going from 2066 to 1727 hours). This positively impacts on the utilization level of resources because of the requirement on classrooms and lecturers decreases. Table 7 summarizes the corresponding information for the five undergraduates programs to which the group consolidation strategy was possible to implement.

Table 7. Programs with Consolidated Groups

\begin{tabular}{|l|l|l|l|l|}
\hline \multicolumn{1}{|c|}{ Academic Program } & $\begin{array}{c}\text { H/Sem. Initial } \\
\text { Solution }\end{array}$ & $\begin{array}{l}\text { H/ Sem. Consolidated } \\
\text { Groups }\end{array}$ & $\begin{array}{c}\text { Dif. } \\
\text { H/Sem. }\end{array}$ & $\begin{array}{c}\text { Dif. } \\
\%\end{array}$ \\
\hline Informatics Engineering & 111 & 95 & 16 & 14.4 \\
\hline Economics and International Finance & 162 & 121 & 41 & 25.3 \\
\hline Industrial Engineering & 180 & 154 & 26 & 14.4 \\
\hline International Business Administration & 358 & 216 & 142 & 39.7 \\
\hline Business Administration & 315 & 203 & 112 & 35.6 \\
\hline
\end{tabular}

Source: Torres Ovalle (2013). 


\section{Conclusions}

This paper studied the problem of course timetabling and classroom assignment. A real-life application was considered from Universidad de La Sabana, in Chia, Colombia. Because of its global complexity, a sample of ten undergraduate programs offered by the School of Economics and Management Sciences and the Faculty of Engineering was taken. These two academic units represent a total of $44.64 \%$ of the total number of students registered for the first academic semester of 2012. In addition, these faculties have a variety of resource requirements (e.g., including specialized labs). This allowed an easy generalization of the situation in order to further apply the proposed methodology to the whole university. The goal was to propose a formal mathematical methodology so as to improve the capacity utilization. It is to note that this study is aligned to the strategic front of institutional development related with the "Implementation of new models of university management to leverage institutional development". Experimental results show significant improvements in key indicators in comparison with the actual timetable of the semester under study, reducing operational cost and increasing classroom utilization levels. Besides, a proposal to consolidate some lectureship groups is validated.

At this point, it is important to highlight that, as part of the implementation process, results of this study were presented at the university within the framework of a workshop with key participants of the internal process. As a result, they found viable the actual implementation of the approach, provided that some few additional variables are taken into account. This point is very important since the current work contributes to reduce the gap between theoretical developments and real-life needs at universities, as explained at the beginning of the paper.

Some lines for further research can be proposed. In the first instance, although the proposed methodology and the optimization model provide a timely solution for the problem, it could be interesting to carry out an in-depth analysis from the student standpoint. For example, it seems relevant to analyze in what extend this new timetabling is convenient from a pedagogical point of view. Another important point to consider, and also evidenced during the data collection and processing stages, is the need of a formal systemized tool to collect information from lecturers since it is collected manually and locally at each academic unit. People involved locally on the data collection process do know all details of the process and use non-standardized forms. It is interesting to think about a systematic data collection process using web-based platforms, for 
example. Such data will become an accurate input of the optimization model or decision making tool.

\section{References}

ABDULLAH, S.; BURKE, E.K. and MCCOLLUM, B. An investigation of variable neighbourhood search for the course timetabling problem. Proceedings of the $2^{\text {nd }}$ Multidisciplinary Conference on Scheduling: Theory and Applications (MISTA), New York, 2005, pp. 413-427.

ARNTZEN, H. and LOKKETANGEN, A. A tabu search heuristic for a university timetabling problem. In Ikabaki, T.; NONOBE, K.; YAGIURA, M. (eds.). Metabeuristics: progress as real problem solvers. Vol. 32. Berling: Springer-Verlag, 2005, pp. 65-86.

BURKE, E.K. and PIETROVIC, S. Recent research directions in automated timetabling. European Journal of Operational Research. 2002, vol. 140, pp. 266-280.

CARTER, M.W. A comprehensive course timetabling and student scheduling system the University of Waterloo. In BURKE, E.K. and ERBEN, W. (eds.). Lecture notes in computer science. Vol. 2079. Heidelberg: Springer-Verlag, 2001, pp. 64-84.

CARTER, M.W. and LAPORTE G. Recent developments in practical course timetabling. In BURKE, E.K. and CARTER, M.W. (eds.). Lecture notes in computer science. Vol. 1408. Heidelberg: Springer-Verlag, 1998, pp. 3-19.

DE WERRA, D. An introduction to timetabling. European Journal of Operational Research. 1985, vol. 19, pp. 151-162.

HERNÁNDEZ, R.; MIRANDA, J. and REY, P. Programación de horarios de clases y asignación de salas para la Facultad de Ingeniería de la Universidad Diego Portales mediante un enfoque de programación entera. Revista de Ingeniería de Sistemas. 2008, vol. XXII, pp. 121-141.

KONSTANTINOW, G. and COAKLEY, C. Use of genetic algorithms in reactive scheduling for course timetabling adjustments. In BURKE, E.K. and TRICK, M.A. (eds.). Lecture Notes in Computer Science. Vol. 3616. Heidelberg: Springer-Verlag, 2005, pp. 521-522.

LEWIS, R. A survey of metaheuristics-based techniques for university timetabling problems. OR Spectrum. 2008, vol. 30, pp. 167-190.

MCCULLOM, B. A perspective on bridging the gap between theory and practice in university timetabling. In BURKE, E.K. and RUDOVÁ, H. (eds.). Lecture notes in computer science. Vol. 3867. Berlin: Springer-Verlag, 2007, pp. 3-23.

PILLAY, N. A survey of school timetabling research. Annals of Operations Research. 2013. DOI: 10.1007/s10479-013-1321-8.

ROSSI-DORIA, O.; SAMPLES, M.; BIRATTARI, M.; CHIARANDINI, M.; DORIGO, M.; GAMBARDELLA, L.M.; KNOWLES, J.; MANFRIN, M.; MASTROLILLI, M.; PAECHTER, B.; PAQUETE, L.; STUTZLE, Y. A comparison of the performance of different metaheuristics on the timetabling problem. In BURKE, E.K. and DE CAUSMAECKER, 
P. (eds.). Lecture notes in computer science. Vol. 2740. Heidelberg: Springer-Verlag, 2003, pp. 329-351.

SARMIENTO-LEPESQUEUR, A.; TORRES-OVALLE, C.; QUINTERO-ARAÚJO, C.L.; MONTOYA-TORRES, J.R. Programación y asignación de horarios de clases universitarias: un enfoque de programación entera. Proceedings of the Tenth LACCEI Latin American and Caribbean Conference (LACCEI'2012), Panama City, Panama, July 23-27, 2012. Latin American and Caribbean Consortium of Engineering Institutions (LACCEI Inc), Boca Raton, Florida, USA, 2012. (ISBN: 13 978-0-9822896-5-5). CD-ROM, paper 027.

SCHAERF, A. A survey of automated timetabling. Artificial Intelligence Review. 1999, vol. 13, pp. 87-127.

SOCHA, K.; KNOWLES, J. and SAMPLES, M. A max-min ant system for the university course timetabling problem. In DORIGO, M.; DI CARO, G.A.; SAMPLES, M. (eds.). Lecture notes in computer science. Vol. 2463. Heidelberg: Springer-Verlag, 2002, pp. 1-13.

TORRES OVALLE, C. Programación de horarios y asignación de aulas de clases universitarias [trabajo de grado]. Maestría en Gerencia de Operaciones, Universidad de La Sabana, Chía, Colombia, 2013. 
